\title{
Teaching reading by using visual scaffolding strategy for the eighth grade students of SMPN 1 Takeran
}

\author{
Fahrul Aditiansyah \\ Universitas PGRI Madiun, Indonesia \\ aditiansyah11@gmail.com
}

\begin{abstract}
The purpose of this study was to describe the application of the Visual Scaffolding strategy in reading in the eighth grade at SMPN 1 Takeran. Visual scaffolding is a strategy that is given to students for reading learning. In reading learning, students feel reading is one of the skills that is difficult to master where students have difficulty interpreting, and explain the meaning of meaning in the text. For that teachers use the Visual Scaffolding strategy where in teaching and learning activities teachers use visual media such as images, videos and movements to make students better understand teaching materials.
\end{abstract}

Keywords: teaching, Reading, Visual Scaffolding

\section{INTRODUCTION}

There are so many languages in this world, English is one of the languages, and it became an international language that is used to communicate in the world. People from different countries communicate in English. They show and transfer their meaning by using English to other people from different nations. In some countries, English is the first or the second language, but in Indonesia, English is a foreign language that is taught in the school. It means that the people in Indonesia do not use English as their daily life conversation, they usually use English in some conditionals such us: communicating with tourists, communicating in their work, teaching and learning process in school etc.

In Indonesia, English is one of important lessons in teaching and learning process. It is proven by including English as one of the lessons that are tested in national final examination for reaching graduation. English is taught by the teachers to the students with the goal that the students will understand and apply the English lessons. Reading is one of the main skills in English activities, according to Nunan (2005:69) "Reading is useful a set of skill that involve making sense and deriving meaning from the printed word". It means that reading is an activity to understand the meaning by using printed word.

Actually, in teaching and learning English process, the students still have difficulties in learning English. Based on the interview with the students the researcher finds that there are some problems in teaching learning process especially in English reading, such us: they are confused in the meaning of the text, hard in pronunciation, difficult in explaining the meaning and etc. so, those are the difficulties in learning process.

Based on the problems and causes above, the research can be concluded that the students need something that help them in teaching learning process, something that help them to feel the experiences that help them read. In this case, the researcher will use Visual scaffolding strategy. According to Burns (in the internet Journal of Titimarni, http://www.jurnal.stkip-pgrisumbar.ac.id/)"Visual scaffolding is a strategy for teaching English language learners that utilize drawing, photograph and other visual in order to help students to understand more about the language used in each lesson". It means that visual scaffolding is a strategy that uses drawing, photo and other 
visual to make students understand well. By using picture, photograph etc, it can help the learning process because it will give students some experiences that make them learn easier.

The researcher hopes that it can help the students in teaching and learning process. So, it will give the students real learning experiences and strategy that make them can understand the materials and build the student's interest with teaching and learning process. From the explanation above, the researcher wants to conduct the research on "Teaching Reading by Using Visual Scaffolding Strategy for the 8th Grade Students at SMP N 1 Takeran".

\section{METHOD}

The research conducted at SMPN 1 Takeran. The location is on Ds. Jomblang, Kec. Takeran, Kab. Magetan from February up to July 2014. In this research, the research uses Qualitative approach. According to Hancock et al (2009:7) "Qualitative research is concerned with developing explanations of social phenomena. That is to say, it aims to help us to understand the social world in which we live and why things are the way they are". It means that qualitative research concern on social phenomena in the live and why the things are.

The type of the research is descriptive research. According to Bogdan and Biklen (2007:5) "Qualitative Research is descriptive. The data collected take the form of words or pictures rather than numbers. The written results of the research contain quotations from the data to illustrate and substantiate the presentation." It means that qualitative research is describing the data from the field into words and pictures, and less number.

The sources of the data in this research are social situation, participant or informant, and document. In this case, the researcher observes the activity of Teaching Reading by using Visual Scaffolding Strategy for the Eighth Grade Students of SMPN 1 Takeran in the Academic year 2014/2015 especially 8C which consists of 20 students. There are 10 males and 10 females and the English teacher of this class.

After the data are collected, the researcher has to analyze the data, the data analyzing technique which is used in this research is divided into five main phases. According to Yin (2011:177) "(1) Compiling, (2) Disassembling, (3) Reassembling (and Arraying), (4) Interpreting, and (5) Concluding". It means that there are five main phased in analyzing the data of the research. In a research, the researcher has to find the validity of the data gotten. In this research, the researcher uses Triangulation. According to Flick (2009:444) "Triangulation as a keyword is used to name the combination of different methods, study group, local and temporal setting and different theoretical perspective in dealing with phenomenon." It means that triangulation is the way to combine the data with the phenomenon. In this research, the researcher does three data collection procedures: observation, interview and documentation to verify the data.

\section{FINDING AND DISCUSSION}

Teaching Reading by Using Visual Scaffolding Strategy for the Eighth Grade Students of SMP N 1 Takeran is divided into three main steps, those are pre-activity, whilst-activity and postactivity. Firstly, pre-activity is consisted of greeting and checking the attendant list. Secondly is whilst-activity, the students explains the related vocabularies that probably will be used in the materials, teacher shows the pictures and videos of that is related with material. The teacher also uses gesture when it is needed. After that, the teacher gives the descriptive text to the students, the teacher discusses the text with the students, when in this phase, the teacher also goes around the class to check the students if they are finding difficulties. The teacher explains the materials, and then gives some question to students to be done. The last is post-activities. In post-activities the teacher asks the students if they find some difficulties, then conclude the materials for today and finally close the lesson. 
The advantages and the disadvantages in Teaching Reading by Using Visual Scaffolding Strategy for the Eighth Grade Students of SMP N 1 Takeran are gotten by doing some interview with the teacher and the students related with the visual scaffolding strategies. The advantages of visual scaffolding in teaching reading according to journal from Titimarni (http://www.jurnal.stkip-pgrisumbar.ac.id) "The visual scaffolding strategy makes students easy to memorable the words and easy to understand the meaning of the text, and then this strategy gave positive effect in improving students' reading comprehension." While based on the observation and teacher and students interview show that the advantages of Visual Scaffolding Strategy are: a). The Teacher can deliver materials easily by using pictures, videos and gestures, b). The students are motivated for learning the material, c). The students are active when discussing the materials, d). The students are easier in understanding the materials and e). The class is fun. Besides, there are also disadvantages of Teaching Reading by using Visual Scaffolding Strategy for the Eight Grade Students of SMP N 1 Takeran, the disadvantages are: a). The teacher is not easily finding related pictures and videos with the materials, b). Visual Scaffolding Strategy needs much time and c). The classroom becomes noisy.

The way to fix the disadvantages of Teaching Reading by Using Visual Scaffolding Strategy for the Eighth Grade Students of SMP N 1 Takeran are: a). The teacher can uses internet to find the suitable pictures easily, b). The teacher has important role to manage the time in teaching and learning activities and c). Teacher takes all the condition as the controller of the class, teacher knows when the students answer together, giving their idea or asking some question. So, the noisy of the class can be reduced.

\section{CONCLUSION}

Teaching Reading by Using Visual Scaffolding Strategy for the Eighth Grade Students of SMP N 1 Takeran is divided into two main stages, those are preparation and presentation. Preparation are making syllabus, RPP, collecting pictures, finding the vocabularies to be tough to the students. Presentation is the stage of teaching and learning process. These stages are divided into three: preactivity, whilst-activity and post-activity.

There are some advantages in teaching reading by using visual scaffolding strategy. They are: The Teacher can deliver materials easily by using pictures, videos and gestures; the students are motivated for learning the material; the students are active when discussing the materials; the students are easier in understanding the materials; the class is fun. There are also some disadvantages in teaching reading by using visual scaffolding strategy for eight grade students. They are: the teacher is not easily finding related to the pictures and videos with the materials; Visual Scaffolding Strategy needs much time; the classroom becomes noisy. The way to fix the disadvantages of teaching reading by using Visual Scaffolding Strategy for the eight grade students of SMP N 1 Takeran are: the teacher can uses internet to find the suitable pictures easily; the teacher has an important role to manage the time in teaching and learning activities; teacher takes all the condition as the controller of the class; teacher knows when the students answer together, giving their idea or asking some question. So, the noisy of the class can be reduced. The researcher gives suggestions for the English teacher, students and the future researcher. For the English teacher is suggested to use Visual scaffolding in the class in teaching reading. It can help the students' reading ability. For the researcher suggests the students to be brave in answering the questions and explaining their idea. For the future researcher is expected to do a research about using Visual scaffolding in teaching the other skills.

\section{REFERENCES}

Bodgan, R. \& Biklen, S. (2007). Qualitative Research for Education. Boston, Mass.: Pearson A\& B.

Brown, H. D. (2000). Principles of Language Learning and Teaching. San Francisco: Addison Wesley Longman Inc. 
English Teaching Journal, Vol. 5 No. 1, Juni 2017

ISSN: 2338-2678

Flick, U. (2009). An Introduction to Qualitative Research, Fourth Edition. London: Sage Publication Grabe and Stoller. (2002). Teaching and Researching Reading. Australia: Longman.

Hancock, O., and Windridge, W. (2007). An Introduction to Qualitative Research. The NIHR Research Design Service.

Herrel and Jordan. (2008). Fifty Strategies for Teaching English. California: Prantice-Hall.

Nunan, D. (2005). Practical English Language Teaching. New York: The McGraw-Hill.

Titimarni. The Effect of Using Visual Scaffolding Strategy Towards Students' Reading Comprehension. (http://www.jurnal.stkip-pgrisumbar.ac.id/MHSING/index.php/MHSING20121/article/download/134/131downloaded at April, 10 2013)

Yin, R. (2011). Qualitative Research from Start to Finish. New York: Guildford 